\title{
Identifikasi Miskonsepsi Mahasiswa tentang Mikrobiologi melalui Pembelajaran Menggunakan Media Gambar
}

\author{
Mar'atul Afidah \\ Universitas Lancang Kuning \\ E-mail: email: maratul@unilak.ac.id
}

\begin{abstract}
Abstrak
Pembelajaran mikrobiologi bersifat abstrak menyebabkan mahasiswa sulit memahami konsep sehingga memungkinkan terjadinya miskonsepsi. Penelitian ini menggunakan metode deskriptif yang bertujuan untuk mengidentifikasi tingkat miskonsepsi mahasiswa pendidikan biologi FKIP Universitas Lancang Kuning tentang pembelajaran mikrobiologi menggunakan media gambar. Penelitian ini dilaksanakan di FKIP Unilak pada semester ganjil Tahun Ajaran 2018/2019. Populasi penelitian berasal dari seluruh mahasiswa Pendidikan Biologi yang terdaftar dan mengontrak mata kuliah Mikrobiologi pada semester 3. Teknik pemilihan sampel adalah dengan total sampling. Teknik pengumpulan data dilakukan dengan memberikan tes tentang konsep mikrobiologi yang berupa gambar. Bentuk instrument tes yang digunakan berupa tes tulis pilihan ganda yang dilengkapi dengan skala keyakinan menjawab soal berupa skala Certainty of Response Index (CRI) dengan skala 6 yaitu 0 sampai 5. Pengumpulan data dengan memberikan satu kali tes setelah pembelajaran menggunakan media gambar. Data yang dikumpul dianalisis menggunakan Teknik Certainty of Response Index. Hasil analisis data dapat diidentifikasi konsepsi yang terjadi pada mahasiswa yang dikelompokkan atas paham konsep, miskonsepsi dan tidak paham tentang konsep mikrobiologi. Hasil penelitian menunjukkan bahwa ditemukan 36,32\% (Sedang) terjadi miskonsepsi terhadap media gambar materi mikrobiologi, dengan temuan tersebut diharapkan dapat menjadi bahan kajian untuk menerapkan metode dan sumber belajar serta media pembelajaran yang tepat dalam proses pembelajaran mata kuliah bidang studi Biologi lainnya.
\end{abstract}

Kata Kunci: Miskonsepsi, Media Gambar, Mikrobiologi

\section{Identification of Students' Misconception about Microbiology through Learning Using Pictures}

\begin{abstract}
Microbiology learning is abstract in nature, making it difficult for students to understand concepts so that misconceptions can occur. This study uses a descriptive method that aims to identify the level of misconception of biology education students at FKIP Lancang Kuning University about microbiology learning using pictures. This research was conducted at FKIP Unilak in odd semester 2018/2019 Academic Year. The population came from all Biology Education students who registered and contracted Microbiology courses in semester 3. The sample selection technique was total sampling. Data collection techniques were carried out by providing tests on microbiological concepts in the form of images. The form of the test instrument used in the form of a multiple choice writing test that is equipped with a scale of confidence to answer questions in the form of the Certainty of Response Index (CRI) with a scale of 6 is 0 to 5. Data collection was one test after learning to use pictures. The data collected was analyzed using the Certainty of Response Index Technique. The results of data
\end{abstract}


analysis can be identified conceptions that occur in students who are grouped on understanding concepts, misconceptions and not understanding about microbiological concepts. The results showed that $36.32 \%$ (moderate) found misconceptions about the pictures of microbiological concept, with these findings expected to be a study material for applying methods and learning resources as well as appropriate learning media in the learning process of other Biology subject courses.

Keywords: Misconceptions, Pictures, Microbiology

\section{PENDAHULUAN}

Permendiknas No. 22 tahun 2006 tentang Standar Isi memberikan pengertian bahwa Ilmu Pengetahuan Alam (IPA) berkaitan dengan cara mencari tahu tentang alam secara sistematis, sehingga Ilmu Pengetahuan Alam bukan hanya sekedar penguasaan dari kumpulan pengetahuan yang berupa fakta-fakta, konsep-konsep, atau prinsip-prinsip saja tetapi juga merupakan suatu proses penemuan atas fakta-fakta, konsep-konsep atau prinsip-prinsip tersebut. Pendidikan IPA diharapkan dapat menjadi wahana bagi peserta didik untuk mempelajari tentang diri sendiri dan alam sekitar, serta prospek pengembangan lebih lanjut dan dalam menerapkannya di dalam kehidupan sehari-hari. Jadi proses pembelajarannya lebih menekankan pada pemberian pengalaman langsung bagi peserta didik untuk mengembangkan kompetensi agar tercapai konsep secara ilmiah.

Saat ini pelaksanaan pembelajaran Biologi khususnya mata kuliah mikrobiologi semester 3 FKIP Unilak masih didominasi oleh suatu situasi dan keadaan di kelas yang masih terfokus pada dosen. Dosen masih menjadi sentral dalam kegiatan kelas dan dosen masih sebagai sumber utama dari pengetahuan, sehingga diskusi masih menjadi pilihan utama dalam mengajar. Aktivitas mahasiswa dalam kegiatan belajar mengajar masih kurang berinovasi. Penggunaan media pembelajaran sebagai penyampai pesan masih kurang digunakan. Proses pembelajaran yang monoton ini menyebabkan mahasiswa menjadi kurang aktif atau bersifat pasif, tidak termotivasi dan minat terhadap pelajaran mikrobiologi dinilai dosen masih rendah. Pembelajaran mikrobiologi yang bersifat abstrak, menyebabkan mahasiswa sulit untuk memahami konsep mikrobiologi yang mengakibatkan terjadinya miskonsepsi mahasiswa. Akibatnya bisa berdampak pada prestasi belajar mahasiswa, sehingga mahasiswa mendapatkan nilai yang kurang memuaskan sesuai yang mereka diharapkan.

Alat ukur untuk mengidentifikasi miskonsepsi peserta didik telah banyak dikembangkan oleh ahli evaluasi. Salah satu teknik yang telah dapat mengidentifikasi kemampuan konsep dan miskonsepsi mahasiswa adalah teknik Certainty of Response Index (CRI). Teknik Certainty of Response Index (CRI) ini merupakan salah satu teknik mengidentifikasi konsepsidan miskonsepsi yang telah dikembangkan oleh para ahli evaluasi pendidikan.Teknik ini dikembangkan oleh Hasan dan kawankawan (Tayubi, 2006). Teknik ini mengungkap tingkat keyakinan calon guru biologi terhadap penguasaan konsep biologi dari hasil tes yang dilengkapi skala keyakinan jawaban. Hal ini sangat diperlukan untuk kepercayaan dirinya dalam memtransferkan ilmu pengetahuan kepada peserta didiknya.Certainty of Response Index (CRI) adalah teknik pengukuran tingkat keyakinan calon guru biologi terhadap konsep biologi, khususnya konsep mikrobiologi.

Bila calon guru biologi (mahasiswa) dalam menjawab pertanyaan 
yang berkaitan dengan konsep mikrobiologi adalah benar dan memiliki tingkat keyakinan yang tinggi terhadap konsep tersebut maka mahasiswa tersebut diidentifikasi sebagai menguasai konsep dengan baik. Jika jawaban mahasiswa adalah salah dan tingkat keyakinan terhadap jawaban tinggi maka diindentifikasikan bahwa mahsiswa mengalami miskonsepsi. Jika mahasiswa menjawab jawaban yang salah dan tingkat keyakinan rendah maka mahasiswa diidentifikasikan sebagai kurang pengetahuan tentang konsep tersebut. Oleh sebab itu penting dilakukan suatu penelitian analisis konsepsi mikrobiologi mahasiswa calon guru biologi.

Berdasarkan latar belakang di atas, maka dilakukan penelitian tentang Identfikasi Miskonsepsi Mahasiswa pada Pembelajaran Menggunakan Media Gambar pada konsep Mikrobiologi Mahasiswa Pendidikan Biologi Ta 2018/2019. Tujuan penelitian ini adalah untuk mengetahui tingkat miskonsepsi mahasiswa pada konsep mikrobiologi dalam pembelajaran menggunakan media Gambar.

\section{Media Pembelajaran}

Menurut asal usulnya kata media berasal dari bahasa latin merupakan bentuk jamak dari medius (Arsyad, 2007). Secara harfiah berarti tengah, perantara atau pengantar. Media merupakan perantara untuk menyampaikan pesan. Berdasarkan Association of Education and Communication Technology (AECT) keduanya menyatakan bahwa media merupakan segala bentuk atau saluran orang yang digunakan untuk menyalurkan atau menyampaikan pesan/informasi.

Satu hal yang utama dan menantang dalam memutuskan rancangan mengajar adalah menentukan medium atau media yang dapat digunakan untuk menyampaikan pengajaran. Penentuan media yang akan digunakan didasarkan pada apa yang akan diajarkan, bagaimana diajarkan dan bagaimana akan dievaluasi dan siapa yang menjadi siswa.

Media pembelajaran secara umum adalah alat bantu proses belajar mengajar. Segala sesuatu yang dapat dipergunakan untuk merangsang pikiran, perasaan, perhatian dan kemampuan atau keterampilan pebelajar sehingga dapat mendorong terjadinya proses belajar. Batasan ini cukup luas dan mendalam mencakup pengertian sumber, lingkungan, manusia dan metode yang dimanfaatkan untuk tujuan pembelajaran / pelatihan.

\section{Konsepsi dan Miskonsepsi}

Istilah konsep dan konsepsi dalam penggunaannya sering dipertukarkan. Keduanya berbeda baik dalam pengertian maupun penggunaannya. Konsep bersifat lebih umum dan dikenal atau diumumkan berdasarkan kesepakatan, sedangkan konsepsi bersifat khusus atau spesifik dan individual (Rustaman, et al. 2003). Menurut Ausubel (Dahar, 2011) konsep adalah benda-benda, kejadian-kejadian, situasi-situasi atau ciri khas yang terwakili dalam setiap budaya oleh benda atau simbol. Rosser (Dahar, 2011) menyatakan konsep merupakan suatu abstraksi yang mewakili satu kelas objek-objek, kejadiankejadian, kegiatan-kegiatan atau hubungan-hubungan yang mempunyai atribut-atribut yang sama. Jadi konsep merupakan abstraksi dari ciri-ciri dari sesuatu yang mempermudah komunikasi antar manusia yang memungkinkan manusia berpikir (bahasa adalah alat berpikir).

Berg (1991) menyatakan perbedaan konsepsi antara individu mahasiswa disebabkan oleh beberapa faktor, yaitu:(1) pengetahuan dan pengalaman berhubungan dengan yang telah dimilikinya, (2) struktur pengetahuan yang telah terbentuk di dalam otaknya, (3) perbedaan kemampuan dalam hal: (a) menentukan apa yang diperhatikan waktu belajar, (b) menentukan apa yang masuk ke otak, (c) menafsirkan apa yang masuk otak, (d) perbedaan apa yang disimpan di dalam otak. Dengan demikian 
apabila seorang mahasiswa pasif, jumlah konsepsinya akan sedikit, sedangkan apabila seorang mahasiswa aktif yang telah terlibat dalam proses pembelajaran, maka konsepsinya akan semakin lebih baik.

\section{Analisis dan Identifikasi miskonsepsi dengan Certainty of Response Index (CRI)}

CRI seringkali digunakan dalam survei-survei, terutama yang meminta responden untuk memberikan derajat kepastian yang dia miliki dari kemampuannya untuk memilih dan menggunakan pengetahuan, konsep, atau hukum yang terbentuk dengan baik dalam dirinya untuk menentukan jawaban terhadap suatu pertanyaan. Menurut Hasan et al (1999), CRI memiliki skala enam (05) dengan rincian sebagai berikut: $0=$ Totally guessed answer (semata-mata menebak), 1=Almost guess (hampir menebak), $2=$ Not sure (tidak yakin benar), $3=$ Sure (yakin benar), 4=Almost certain (hampir pasti benar) dan 5=Certain (pasti benar) (Hasan et al. 1999). Angka 0 menandakan responden tidak memahami konsep sama sekali tentang metoda atau hukum-hukum yang diperlukan untuk menjawab suatu pertanyaan (jawaban ditebak secara total), sementara angka 5 menandakan kepercayaan diri yang penuh atas kebenaran pengetahuan tentang prinsip-prinsip, hukum-hukum dan aturanaturan yang dipergunakan untuk menjawab terhadap suatu pertanyaan (soal), tidak ada unsur menebak sama sekali. Dengan kata lain, ketika seorang siswa diminta untuk memberikan CRI bersamaan dengan setiap jawaban suatu pertanyaan (soal), sebenarnya dia diminta untuk memberikan penilaian terhadap dirinya sendiri akan kepastian yang dia miliki ketika memilih aturan, prinsip dan hukum yang telah berhasil dikuasainyasehingga dia dapat menentukan jawaban dari suatu pertanyaan.

Jika derejat kepastiannya rendah (CRI 0-2), maka hal ini menggambarkan bahwa proses penebakan (guesswork) memainkan peranan penting dalam menentukan jawaban. Tanpa memandang apakah jawaban benar atau salah, nilai CRI yang rendah menunjukkan unsur menebak, yang secara tidak langsung mencerminkan ketidaktahuan konsep yang mendasari penentuan jawaban.Jika CRI tinggi (3-5), maka responden memiliki tingkat kepercayaan diri (confidence) yang tinggi dalam memilih aturan-aturan dan metodemetode yang digunakan untuk sampai pada jawaban. Dalam keadaan ini (CRI 3-5), siswa memberikan jawaban yang benar, menunjukkan bahwa tingkat keyakinan yang tinggi akan kebenaran konsepsi telah teruji (justified) dengan baik. Akan tetapi, jika jawaban yang diberikan salah, ini menunjukkan adanya suatu kekeliruan konsepsi dalam pengetahuan tentang suatu materi subyek yang dimilikinya, dan dapat menjadi suatu indikator terjadinya miskonsepsi.

Seperti yang telah dikemukakan di atas, CRI merupakan cara pengukuran umum tingkat kepastian siswa menjawab setiap pertanyaan. Indeks ini secara umum tergolong tipe skala Likert. Secara khusus, untuk setiap pertanyaan dalam tes berbentuk piihan ganda misalnya, para siswa diminta untuk: (1) memilih jawaban yang dianggap benar dan alternatif pilihan yang tersedia, (2) memberikan CRI, antara $0-5$, untuk setiap jawaban yanng dipilihnya. CRI 0 diberikan jika jawaban yang dipilih hasil tebakan murni, sedangkan CRI 5 diberikan jika jawaban yang dipilih atas dasar pengetahuan dan skill yang sangat ia yakini kebenarannya. Kriteria jawaban dan tinggi rendahnya CRI dapat dilihat pada Tabel 1 dan Tabel 2.

\section{METODE}

Metode penelitian ini menggunakan metode deskriptif. Penelitian ini dilaksanakan dengan cara mengidentifikasi dan menganalisis miskonsepsi mahasiswa calon guru Biologi dalam memahami konsep-konsep mikrobiologi dalam pembelajaran 
menggunakan media gambar. Data penelitian yang telah dikumpulkan dianalisis dengan menggunakan teknik CRI (Certainty of Response Index) dan dinterpretasikan, dan selanjutnya dideskripsikan untuk menggambarkan miskonsepsi yang terjadi pada subjek penelitian.

Penelitian ini dilakukan pada bulan November sampai Desember tahun 2018. Tempat penelitian adalah di program studi Pendidikan Biologi Fakultas Keguruan dan Ilmu Pendidikan Universitas Lancang Kuning, Pekanbaru, Riau. Populasi penelitian adalah mahasiswa pendidikan Biologi Fakultas Keguruan dan Ilmu Pendidikan Universitas Lancang Kuning yang terdaftar pada semester 3. Penetapan sampel dengan teknik total sampling.

Penelitian ini dilakukan dengan tiga tahap, yaitu tahap persiapan, pelaksanaan, dan analisis data.

\section{Tahap Persiapan}

Melakukan observasi kajian pustaka yang sesuai dengan rumusan masalah yang akan diteliti, dan melakukan orientasi lapangan serta koordinasi antara peneliti dengan ketua jurusan biologi.

Menyusun perangkat instrument berupa lembar tes. Tes ini bersifat konseptual yang dibuat dan bentuk tes obyektif model pilihan ganda dengan empat pilihan jawaban. Setiap soal menguji pemahaman mahasiswa terhadap konsep yang tercakup konsep-konsep mikrobiologi. Tes ini dilakukan satu kali yang dilengkapi dengan nilai skala keyakinan CRI (Certainty of Response Index) dengan tujuan untuk mengukur tingkat keyakinan menjawab tes pada konsep yang diukur.

\section{Tahap Pelaksanaan Penelitian}

Tahap ini merupakan tahap pengumpulan data. Langkah-langkah yang dilakukan adalah sebagai berikut:

a. Melakukan tes dengan soal tes kemampuan konsepsi Mikrobiologi dengan tipe pilihan ganda dan skala CRI (Certainty of Response Index).

b. Menganalisa data hasil jawaban mahasiswa pada tes. Hasil jawaban CRI pada tes dikelompokkan ke dalam jenis-jenis konsepsi yang terjadi, didasarkan pada tabel kriteria konsepsi.

c. Melakukan pengolahan data dan analisis data dari hasil tes penelitian menggunakan teknik Certainty of Response Index (CRI).

d. Menyusun laporan hasil penelitian

\section{Analisis Konsepsi Mahasiswa}

Suatu teknik yang digunakan dalam mengidentifikasi miskonsepsi yang terjadi pada mahasiswa tentang konsep mikrobiologi adalah teknik CRI atau certainty of response index. Data penelitian yang diperoleh dari hasil tes dapat diolah dan dianalisis dengan langkah-langkah sebagai berikut:

1) Soal tes dilengkapi dengan lembar pilihan jawaban dan skala CRI yaitu tingkat keyakinan terhadap pilhan jawaban, skala CRI yang digunakan adalah skala 6 , dimulai dengan skala 0 sampai 5.

2) Lembar jawaban dan skala CRI yang telah dikumpulkan kemudian dilakukan penilaian. Penilaian hasil tes yang diberikan penilaian untuk jawaban mahasiswa diberi skor 1 jika jawaban benar dan 0 (nol) jika jawaban mahasiswa salah.

3) Penentuan skala keyakinan terhadap jawaban atau CRI pada mahasiswa untuk setiap soal disesuaikan dengan Tabel kriteria konsepsi berikut:

a) Paham: mahasiswa dikategorikan paham konsep jika jawaban tes dinilai benar dengan tingkat keyakinan atau skala CRI mahasiswa memilih 3,4 atau 5, dalam arti skor CRI $>2,5$.

b) Menebak: mahsiswa dikategorikan menebak jika jawaban tes obyektifnya dinilai benar dengan tingkat keyakinan atau skala CRI 
mahasiswa memilih 0 , 1 , atau 2 , dalam arti skor $\mathrm{CRI}<2,5$.

c) Miskonsepsi: mahasiswa dikategorikan mengalami miskonsepsi jika jawaban tes obyektifnya salah dengan tingkat keyakinan atau CRI mahasiswa memilih 3,4 atau 5, dalam arti skor CRI $>2,5$.

d) Tidak paham konsep: jika jawaban tes obyektifnya salah dengan tingkat keyakinan jawaban atau CRI mahasiswa memilih 0, 1 , atau 2, dalam arti skor CRI $<2,5$.

4) Penentuan tingkat konsepsi dan miskonsepsi mahasiswa ditentukan berdasarkan hasil tes.

5) Menghitung persentase konsepsi.

6) Persentase tingkat miskonsepsi mahasiswa diinterpretasikan berdasarkan Tabel 2.

Tabel 1. Kriteria Konsepsi

\begin{tabular}{lll}
\hline \multicolumn{1}{c}{$\begin{array}{c}\text { Kriteria } \\
\text { jawaban }\end{array}$} & $\begin{array}{l}\text { CRI rendah } \\
(<2,5)\end{array}$ & $\begin{array}{c}\text { CRI tinggi } \\
(>2,5)\end{array}$ \\
\hline Jawaban & Jawaban & Jawaban \\
benar & benar tapi & benar dan \\
& CRI rendah & CRI tinggi \\
berarti tidak & berarti \\
& tahu konsep & menguasai \\
& lucky & konsep \\
guess $).$ & dengan baik. \\
& & \\
& & Jawaban \\
Jawaban & Jawaban & salah tapi \\
salah & salah tapi & CRI tinggi \\
& CRI rendah & berarti \\
& berarti juga & terjadi \\
& tidak tahu & Miskonsepsi \\
& konsep & \\
\hline
\end{tabular}

( Hasan et al., 1999)

Tabel 2. Kategori Tingkat Miskonsepsi

\begin{tabular}{cc}
\hline Persentase & Kategori \\
\hline $\mathbf{0 - 3 0}$ & Rendah \\
$\mathbf{3 1 - 6 0}$ & Sedang \\
$\mathbf{6 1 - 1 0 0}$ & Tinggi \\
\hline
\end{tabular}

\section{HASIL DAN PEMBAHASAN}

Berdasarkan hasil Analisis data yang diperoleh dari tes penguasaan konsep tentang Mikrobiologi yang diperoleh dari proses pembelajaran menggunakan media gambar maka didapatkan hasil penelitian tentang konsepsi dan miskonsepsi mahasiswa. Dari hasil data penelitian yang dilakukan, data skor hasil tes yang diperoleh dianalisis menjadi nilai, kemudian diinterpretasi ke kategori konsepsi. Kategori konsepsi berdasarkan teknik CRI ada empat kategori yaitu Paham konsep, tidak paham konsep, miskonsepsi dan menebak. Lebih jelasnya dapat dilihat kategori konsepsi seperti tertera pada tabel sebagai berikut:

Tabel 3. Hasil Tes CRI

\begin{tabular}{|c|c|c|c|c|}
\hline \multirow[t]{2}{*}{$\begin{array}{l}\text { No. } \\
\text { soal }\end{array}$} & \multicolumn{4}{|c|}{$\begin{array}{c}\text { Jumlah mahasiswa berdasarkan konsepsi } \\
\text { dengan CRI }\end{array}$} \\
\hline & Paham & Miskonsepsi & $\begin{array}{c}\text { Tidak } \\
\text { Paham }\end{array}$ & Menebak \\
\hline 1 & $\begin{array}{l}31 \\
(82 \%)\end{array}$ & $2(5 \%)$ & $1(3 \%)$ & $4(10 \%)$ \\
\hline 2 & $1(3 \%)$ & $18(47 \%)$ & $\begin{array}{l}17 \\
(45 \%)\end{array}$ & $2(5 \%)$ \\
\hline 3 & $\begin{array}{l}16 \\
(42 \%)\end{array}$ & $7 \quad(18 \%)$ & $\begin{array}{l}4 \\
(11 \%)\end{array}$ & $\begin{array}{l}11 \\
(29 \%)\end{array}$ \\
\hline 4 & $3(8 \%)$ & $19(50 \%)$ & $\begin{array}{l}15 \\
(39 \%)\end{array}$ & $1(3 \%)$ \\
\hline 5 & $\begin{array}{l}4 \\
(11 \%)\end{array}$ & $21(55 \%)$ & $\begin{array}{l}12 \\
(32 \%)\end{array}$ & $1(2.6 \%)$ \\
\hline 6 & $\begin{array}{l}8 \\
(21 \%)\end{array}$ & $17(45 \%)$ & $\begin{array}{l}10 \\
(26 \%)\end{array}$ & $3(7.9 \%)$ \\
\hline 7 & $\begin{array}{l}12 \\
(32 \%)\end{array}$ & $7(18 \%)$ & $\begin{array}{l}8 \\
(21 \%)\end{array}$ & $\begin{array}{l}11 \\
(29 \%)\end{array}$ \\
\hline 8 & $2(5 \%)$ & $16(42 \%)$ & $\begin{array}{l}17 \\
(45 \%)\end{array}$ & $3(8 \%)$ \\
\hline 9 & $\begin{array}{l}1 \\
(2.6 \%)\end{array}$ & $16(42 \%)$ & $\begin{array}{l}18 \\
(47 \%)\end{array}$ & $3(7.9 \%)$ \\
\hline 10 & $0(0 \%)$ & $12(32 \%)$ & $\begin{array}{l}24 \\
(63 \%)\end{array}$ & $2(5 \%)$ \\
\hline 11 & $\begin{array}{l}12 \\
(32 \%)\end{array}$ & $17(45 \%)$ & $\begin{array}{l}6 \\
(16 \%)\end{array}$ & $3(8 \%)$ \\
\hline 12 & $\begin{array}{l}4 \\
(11 \%)\end{array}$ & $13(34 \%)$ & $\begin{array}{l}18 \\
(47 \%)\end{array}$ & $3(7.9 \%)$ \\
\hline 13 & $\begin{array}{l}6 \\
(16 \%)\end{array}$ & $21(66 \%)$ & $3(8 \%)$ & $8(21 \%)$ \\
\hline 14 & $0(0 \%)$ & $15(39 \%)$ & $\begin{array}{l}21 \\
(55 \%)\end{array}$ & $2(5 \%)$ \\
\hline 15 & $\begin{array}{l}24 \\
(63 \%)\end{array}$ & $6(16 \%)$ & $\begin{array}{l}3 \\
(7.9 \%)\end{array}$ & $5(13 \%)$ \\
\hline$\sum$ & 124 & 207 & 177 & 62 \\
\hline$\%$ & 21.75 & 36.32 & 31.05 & 10.88 \\
\hline
\end{tabular}


Berdasarkan hasil analisis data pada Tabel 3 diperoleh konsepsi mahasiswa tentang konsep mikrobiologi. Konsepsi dari teknik CRI yang diperoleh terdiri dari empat kategori yaitu kategori Paham konsep, miskonsepsi, tidak paham konsep dan menebak. Hasil analisis data yang diperoleh bahwa nilai rerata nilai jawaban hasil tes mahasiswa Paham konsep dari media gambar yang disajikan pada saat perkuliahan paling tinggi pada item soal nomor 1 tentang konsep dari gambar Teknik sterilisasi secara Filtrasi yaitu sebesar 31 orang menjawab benar atau dalam persentase $82 \%$ (paham konsep). Item ini miskonsepsi hanya terjadi pada 2 orang saja atau 5\%, sedangkan yang tidak paham 1 orang (3\%) dan menebak hanya 4 orang $(10 \%)$. Pada item soal nomor 2 tentang konsep Bentukbentuk pertumbuhan Bakteri sebesar 1 orang menjawab benar atau dalam persentase 3\% (paham), miskonsepsi hanya terjadi pada 18 orang saja atau dalam persentase $47 \%$, sedangkan yang tidak paham 17 orang atau dalam persentase (45\%) dan menebak hanya 2 orang $(5 \%)$.

Pada item soal nomor 3 tentang konsep Bentuk dan ukuran koloni bakteri, diidentifikasi sebesar 16 orang dalam persentase $42 \%$ (paham), miskonsepsi terjadi pada 7 orang atau dalam persentase $18 \%$, sedangkan yang tidak paham 4 orang atau dalam pesrsentase $(11 \%)$ dan menebak hanya 11 orang (29\%). Pada item soal nomor 4 tentang Gambar Bentuk Virus sebesar 3 orang menjawab benar (11\%) atau pada ketegori paham, miskonsepsi pada 19 orang (50\%), sedangkan yang tidak paham 15 orang (39\%) dan kategori menebak hanya 1 orang (3\%). Pada item soal nomor 5 tentang konsep Gambar Bakteri Sarkina, ditemukan bahwa sebesar 4 orang paham dalam persentase $11 \%$ menjawab benar, miskonsepsi pada 21 orang (55\%), sedangkan yang tidak paham 12 orang atau dalam pesrsentase (32\%) dan menebak hanya 1 orang (3\%). Pada item soal nomor 6 tentang Bentuk Bakteri Vibrio, terdapat sebesar 8 orang menjawab benar atau dalam persentase $21 \%$ (paham), miskonsepsi hanya terjadi pada 17 orang saja atau dalam persentase $45 \%$, sedangkan yang tidak paham 10 orang atau dalam persentase $(26 \%)$ dan menebak hanya 3 orang $(8 \%)$.

Pada Tabel 3, item soal nomor 7 tentang konsep gambar Bentuk Jamur mikroskopis, sebesar 12 orang menjawab benar atau dalam persentase $32 \%$ dengan kategori paham konsep. Pada item ini miskonsepsi hanya terjadi pada 7 orang saja atau dalam persentase $18 \%$, sedangkan yang tidak paham 8 orang atau dalam persentase $(21 \%)$ dan menebak hanya 11 orang $(29 \%)$. Pada item soal nomor 8 tentag konsep gambar Struktur Jamur mikroskopis, diidentifikasi bahwa sebesar 2 orang menjawab benar atau dalam persentase 5\% (paham). Pada item ini miskonsepsi hanya terjadi pada 16 orang saja atau dalam persentase $42 \%$, sedangkan yang tidak paham 17 orang atau dalam pesrsentase $(45 \%)$ dan menebak hanya 3 orang $(8 \%)$.

Pada item soal nomor 9 tentang konsep yang diwakili gambar Jamur Penghasil Antibiotik, diidentifikasi bahwa sebesar 1 orang menjawab benar atau dalam persentase 3\% (paham). Pada item ini miskonsepsi hanya terjadi pada 16 orang saja atau dalam persentase $42 \%$, sedangkan yang tidak paham 18 orang atau dalam pesrsentase $(47 \%)$ dan menebak hanya 3 orang $(8 \%)$. Pada item soal nomor 10 tentang konsep gambar Alga Gleocapsa ditemukan bahwa tidak terdapat mahasiswa yang mengetahui tentang gambar artinya sebesar 0 orang menjawab benar atau dalam persentase 0\% (paham). Pada item ini miskonsepsi hanya terjadi pada 12 orang saja atau dalam persentase $32 \%$, sedangkan yang tidak paham 24 orang atau dalam persentase $(63 \%)$ dan menebak hanya 2 orang (5\%). Pada item soal nomor 11 tentang konsep yang diwakili gambar tentang Struktur Protozoa ditemukan sebesar 12 orang menjawab benar atau dalam persentase $32 \%$ (paham). 
Pada item ini miskonsepsi hanya terjadi pada 17 orang saja atau dalam persentase $45 \%$, sedangkan yang tidak paham 6 orang atau dalam pesrsentase $(16 \%)$ dan menebak hanya 3 orang $(8 \%)$.

Berdasarkan item soal nomor 12 tentang konsep yang diwakili gambar Spesies protozoa yang menyebabkan penyakit keputihan ditemukan bahwa sebesar 4 orang menjawab benar atau dalam persentase $11 \%$ (paham). Pada item ini miskonsepsi hanya terjadi pada 13 orang saja atau dalam persentase $34 \%$, sedangkan yang tidak paham 18 orang atau dalam pesrsentase $(47 \%)$ dan menebak hanya 3 orang (8\%). Pada item soal nomor 13 tentang konsep Virus yang diwakili dengan gambar Struktur Virus T ditemukan bahwa sebesar 6 orang menjawab benar atau dalam persentase $16 \%$ (paham). Pada item ini miskonsepsi terjadi pada 21 orang atau dalam persentase $66 \%$ dengan kategori tinggi, sedangkan yang tidak paham 3 orang atau dalam persentase $(8 \%)$ dan menebak hanya 8 orang $(21 \%)$. Item soal nomor 13 ini adalah miskonsepsi tertinggi pada konsep-konsep mikrobiologi, yaitu konsep struktur virus.

Pada item soal nomor 14 tentang konsep Daur Hidup Virus yang diwakili dengan Gambar daur hidup virus secara Lisis ditemukan bahwa sebesar 0 orang menjawab benar atau dalam persentase $0 \%$ (paham). Pada item ini miskonsepsi hanya terjadi pada 15 orang saja atau dalam persentase $39 \%$, sedangkan yang tidak paham 21 orang atau dalam pesrsentase $(55 \%)$ dan menebak hanya 2 orang $(5 \%)$. Pada item soal nomor 15 tentang konsep Pertumbuhan Bakteri yangdiwakili dengan gambar Proses pengenceran dan Pemurnian Bakteri ditemukan bahwa sebesar 24 orang menjawab benar atau dalam persentase $63 \%$ (paham). Pada item ini miskonsepsi hanya terjadi pada 6 orang saja atau dalam persentase $16 \%$, sedangkan yang tidak paham 3 orang atau dalam persentase $(8 \%)$ dan menebak hanya 5 orang (13\%).
Hasil data penelitian tentang konsepsi mahasiswa dapat digambar secara umum seperti diagram dibawah ini:

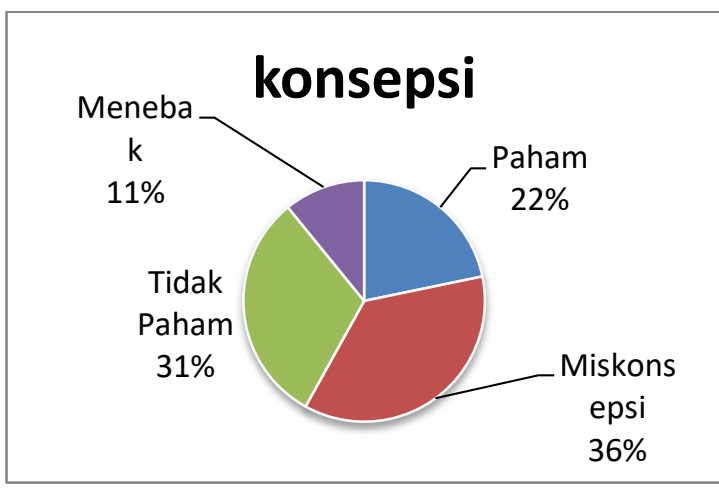

Diagram 1. Hasil Konsepsi

Berdasarkan hasil yang telah diperoleh rerata dari 38 mahasiswa yang menjawab tes hasil belajar tentang konsep mikorbiologi hanya $21,75 \%$ yang paham konsep atau sekitar 9 orang mahasiswa. Sedangkan miskonsepsi yang terjadi pada pembelajaran dengan menggunakan media gambar pada matakuliah mikrobiologi adalah 36,32 kategori sedang. Mahasiswa yang tidak paham konsep diperoleh rerata $31,05 \%$ tidak paham konsep mikrobiologi melalui media gambar. Sedangkan mahasiswa yang menebak jawaban tes penguasaan konsep didapat rerata $10,88 \%$.

Berdasarkan hasil identifikasi konsepsi mahasiswa tentang konsep mikrobiologi ditemukan bahwa secara umum gambar-gambar tentang konsepkonsep yang digunakan sebagai media dalam proses pembelajaran telah dimiskonsepsi oleh mahasiwa. Miskonsepsi tertinggi terjadi pada gambar tentang struktur Virus. Gambar struktur Virus merupakan gambar yang memiliki banyak versi gambar. Ditemukan bahwa semua gambar tentang mikrobiologi telah dimiskonsepsi oleh mahasiswa dengan tingkat miskonsepsi yang berbeda-beda.

Miskonsepsi terjadi pada mahasiswa yang menjawab salah namun rasa percaya diri (tingkat keyakinan tinggi), maka terjadilah miskonsepsi. Dari hasil yang diperoleh rerata miskonsepsi yang terjadi masih pada kategori sedang. 
Tingkat miskonsepsi paling tinggi yang terjadi pada mahasiswa adalah tentang konsep Struktur virus sebesar $66 \%$. Menurut Suparno (2014) miskonsepsi dapat ditimbulkan oleh konteks materi pelajaran yang bersifat abstrak. Struktur virus adalah konsep yang paling kecil ukuran dari organisme mikroskopis.

Menurut Suyanto dan Jihad, (2013), penggunaan media gambar tidak selamanya dapat menghasilkan hasil belajar lebih baik, cepat dan menarik, namun dapat mengasilkan gagalnya siswa dalam menguasai konsep dan informasi yang disampaikan. Hal ini dibuktikan dengan hasil temuan penelitian ini, media gambar yang digunakan dalam pembelajaran telah menimbulkan miskonsepsi pada mahasiswa. Hal ini terjadi dimungkinkan gambar yang disajikan kurang menarik perhatian mahasiswa, dapat juga gambar terlihat monoton menurut mahasiswa karena bentuknya yang mikrokopis dan abstrak sehingga materi dianggap sulit dipahami (Suparno, 2014).

proses $\begin{array}{cc}\text { Sejatinya media gambar dapat } \\ \text { pembelajaran }\end{array}$
mengkomunikasikan konsep-konsep, sehingga mejadi lebih efektif karena siswa dapat menyaksikan gambar yang diajakan oleh guru. Dengan media gambar dapat disampaikan materi yang memberikan nilai yang berarti terutama dalam bentuk pengertian baru, memperjelas pengertian baru, dan memperkuat pengertian tentang suatu konsep tertentu (Suyanto dan Jihad, 2013). Namun media harus memenuhi kriteria-kriteria pemilihan media agar tidak menimbulkan miskonsepsi.

Media gambar yang digunakan dalam pembelajaran Mikrobiologi dimungkinkan belum sepenuhnya memenuhi kriteria media pembelajaran yang baik. Pengambilan gambar yang digunakan dosen saat proses pembelajaran berasal dari hasil penelususran di internet. Kemungkinan gambar yang digunakan adalah gambar dengan tujuan yang belum memenuhi tujuan pembelajaran yang ingin disampaikan dosen kepada mahasiswa, sehingga terjadi miskonsepsi terhadap gambar-gambar tersebut. Salah satu syarat media yang baik adalah media yang selau menunjang tercapainya tujuan pembelajaran, sesuai dengan kemampuan dan daya nalar siswa, sehingga tidak menimbulkan kesalahan persepsi dan miskonsepsi.

Miskonsepsi tidak boleh dibiarkan dalam pemahaman mahasiswa calon guru biologi karena akan dapat ditularkan miskonsepsi tersebut kepada siswanya kelak. Hal ini tidak boleh diabaikan begitu saja, karena jika guru mengalami miskonsepsi maka sangat sulit untuk diperbaiki jika itu telah ditularkan pada peserta didiknya. Pada kegiatan belajar kadangkala gruru sering menyampaikan pendapat dan keyakinannya. Menurut Lickona (2012) ruang kelas bukanlah suatu sarana bagi guru untuk menyatakan pendapat dan keyakinannya. Jika miskonsepsi guru merasal dari intuisi dan pendapatnya bisa saja hal ini dianggap benar oleh siswanya. Pada kenyataannya telah banyak ditemukan miskonsepsi pada guru dan calon guru. Jika guru mengalami miskonsepsi maka akan sulit untuk mengidentifikasi miskonsepsi dan memperbaikinya (Mursalin, 2012).

Miskonsepsi tentang konsepkonsep biologi banyak terjadi pada mahasiswa dan calon guru biologi, hal ini sejalan dengan penelitian yang dilakukan oleh Dikmenli (2010) yang menemukan miskonsepsi terjadi pada konsep biologi yaitu konsep meiosis, konsep meiosis lebih rumit dan sulit untuk dipelajari oleh mahasiswa. Sehingga terjadi kesulitan mahasiswa untuk dapat menguasai materi genetika disebabkan oleh adanya masalah pada konsep mengenai meiosis, mitosis, struktur dan fungsi kromosom. Hal ini menunjukkan mahasiswa mengalami masalah terhadap konsep-konsep dalam Biologi sel, dan kesalahan konsep akan berpengaruh terhadap materi lanjutan seperti genetika, sistem reproduksi, 
pertumbuhan dan perkembangan dan biologi molekuler.

Penelitian yang senada juga pernah dilakukan oleh Murni (2013) yang menyimpulkan bahwa salah satu sebab dapat terjadinya miskonsepsi pada peserta didik adalah karakter konsep yang bersifat abstrak, banyak istilah asing, bahasanya sulit, serta ketidaksiapan mahasiswa dalam menerima materi yang disampaikan oleh dosen. Sama halnya dengan penelitian yang telah dilakukan oleh Mustika et al (2014) bahwa hasil data menunjukkan telah terjadi miskonsepsi yang disebabkan oleh beberapa faktor yaitu penalaran yang salah terhadap suatu konsep yang dipelajari, ketidaklengkapan informasi yang diterima yang berasal dari mahasiswa sendiri, pengalaman dan pengamatan mahasiswa yang keliru, istilah dan konsep yang telah lama, pengalaman belajar di tingkat pendidikan sebelumnya dan kesalahan pada buku teks yang dibaca.

Berdasarkan hasil penelitian dan penelitian yang relevan ada beberapa kemungkinan faktor yang berperan dalam terjadinya miskonsepsi pada mahasiswa, baik dalam diri mahasiswa, media ajar yang digunakan bahkan pada dosen sebagai pengajar di dalam kelas. Dalam hal ini miskonsepsi yang dianalisa dalam hasil penelitian ini adalah pada media pembelajaran yang digunakan saat pelaksanaan pembelajaran. Media pembelajaran sebagai alat dalam menyampaikan pesan dan informasi dari dosen kepada mahasiswa sebagai konsep dasar pengetahuan, namun miskonsepsi masih terjadi pada mahasiswa dimungkinkan berasal dari media yang belum memenuhi kriteria media pembelajaran yang sesuai dengan tujuan pembelajaran. Oleh sebab itu penggunaan media gambar dalam proses pembelajaran harus dieprthatikan dengan baik tujuan dan kebenaran konsep yang diwakili dengan gambar-gambar sehingga hasil belajar yang diinginkan dapat tercapai secara maksimal tanpa menimbulkan miskonsepsi, terutama bagi calon guru biologi.

\section{KESIMPULAN}

Hasil penelusuran identifikasi miskonsepsi dan konsepi mahsiswa tentang mikrobiologi melalui pembelajaran menggunakan media gambar dapat disimpulkan bahwa telah teridentifikasi mahasiswa mengalami miskonsepsi tentang mikrobiologi dengan nilai $36,32 \%$ pada kategori miskonsepsi tingkat sedang, dengan konsep yang dimiskonsepsi tertinggi tentang gambar-gambar virus.

Bagi peneliti yang ingin melanjutkan penelitian sebaiknya membuat item soal yang lebih rinci dengan media gambar dan lebih jelas keterangannya serta dalam jumlah yang banyak sehingga dapat divalidasi dan digunakan sebagai item soal yang lebih baik.

\section{DAFTAR PUSTAKA}

Arsyad, A. (2007). Media Pembelajaran. Raja Grafindo Persada: Jakarta.

Berg, E.V. (1991). Miskonsepsi Fisika dan Remediasi. Salatiga: UKSW.

Dahar, R.W. (2011). Teori- teori Belajar dan Pembelajaran. Jakarta: Erlangga.

Murni, D. (2013). Identifikasi Miskonsepsi Mahasiswa pada Konsep Substansi Genetika Menggunakan Certainty of Response Index (CRI).Prosiding Semirata FMIPA Universitas Lampung, 2013. Hal.207-211.

Dikmenli. (2010). Misconceptions of Cell Division Held by Student Teachers in Biology: A Drawing analysis. Scinetific Research and Essay, Vol. 5(2), p.235-247 
Hasan, S., Bagayoko, D., dan Kelley, E.L. (1999). Misconceptions and the Certainty of Response Index (CRI). Phys.Educ.34 295:

Lickona, T. (2012). Educating for

Character. Jakarta: Bumi Aksara.

Mursalin, H. (2012). Model Diklat Penanggulangan Miskonsepsi Guru Fisika pada Topik kelistrikan dan Kemagnetan melalui Simulasi Komputer. Universitas Pendidikan Indonesia. Bandung. Tidak Diterbitkan.

Mustika, A.A, Yusminah H, dan Andi, F.A. (2014). Identifikasi Miskonsepsi Mahasiswa Biologi Universitas Negeri Makassar pada Konsep Genetika dengan Metode CRI. Jurnal sainsmat. Vol III no 2. Makasar.

Rustaman, N.Y., Soendjojo, D., Yudianto,S.A., Achmad,S., Subekti,R., Rochintaniawati,D., dan Nurjhani, M.K . (2003). Strategi Belajar Mengajar Biologi. Bandung: Jurusan Pendidikan Biologi FPMIPA UPI.

Suparno, P. (2014). Miskonsepsi dan Perubahan Konsep Dalam Pendidikan Fisika. Jakarta: Grasindo.

Suyanto \& Jihad, A. (2013). Menjadi Guru Profesional. Jakarta: Erlangga.

Tayubi, Y. R. (2006). Identifikasi Miskonsepsi pada Konsep-Konsep Fisika Menggunakan Certainty of Response Index (CRI). Mimbar Pendidikan. Vol.3 (XXIV). 